\title{
POTENTIALS OF RICE STRAW, RICE HULL AND SAW DUST ON THE GROWTH AND YIELD PERFORMANCE OF RICE GROWN UNDER VARIABLE MOISTURE CONDITIONS IN SALINE SOIL
}

\author{
SUMA AKTER ${ }^{1}$, MD. HARUNOR RASHID KHAN \\ AND MOHAMMED SADID HOSSAIN \\ Department of Soil, Water and Environment \\ University of Dhaka, Dhaka-1000, Bangladesh
}

\begin{abstract}
A field trial was carried out with rice (BRRI 64) grown in saline soil at Kuakata of Patuakhali District to evaluate the potential of rice straw, rice hull and saw dust each applied at the rates of $0,4,8 \mathrm{t} \mathrm{ha}^{-1}$ in moist and saturated conditions. Growth parameters and yield of rice were found to increase significantly $(\mathrm{p} \leq 0.05)$ with the increased rates regardless of kinds of organic treatments under both the conditions. The highest plant heights ( $89 \mathrm{~cm}$ in moist and $101 \mathrm{~cm}$ in saturated condition) were recorded at maturity in the treatment, which received the combination $\left(\mathrm{RH}_{8} \mathrm{RS}_{8} \mathrm{SD}_{8}\right)$ of highest rates of these 3 organic amendments. The lowest plant heights $(73 \mathrm{~cm}$ in moist and $77 \mathrm{~cm}$ in saturated) were recorded in control condition $\left(\mathrm{RH}_{0} \mathrm{RS}_{0} \mathrm{SD}_{0}\right)$. The maximum numbers of tillers were observed in $\mathrm{RH}_{8} \mathrm{RS}_{8} \mathrm{SD}_{8}$ and $\mathrm{RH}_{8} \mathrm{RS}_{4} \mathrm{SD}_{8}$ followed by $\mathrm{RH}_{8} \mathrm{RS}_{8} \mathrm{SD}_{4}, \mathrm{RH}_{8} \mathrm{RS}_{4} \mathrm{SD}_{4}$ and $\mathrm{RH}_{4} \mathrm{RS}_{8} \mathrm{SD}_{8}$ treatments at saturated condition. The straw dry matter and grain yields of rice were also found to vary significantly $(\mathrm{p} \leq 0.05)$ due to single application of rice hull, rice straw, saw dust and moisture conditions but their combined effects were found to be significantly better at the higher levels. The highest grain yield $\left(6.6 \mathrm{t} \mathrm{ha}^{-1}\right)$ was recorded in $\mathrm{RH}_{8} \mathrm{RS}_{8} \mathrm{SD}_{8}$ treatment followed by $\mathrm{RH}_{8} \mathrm{RS}_{8} \mathrm{SD}_{4}, \mathrm{RH}_{8} \mathrm{RS}_{4} \mathrm{SD}_{8}, \mathrm{RH}_{8} \mathrm{RS}_{4} \mathrm{SD}_{4}$ and $\mathrm{RH}_{4} \mathrm{RS}_{8} \mathrm{SD}_{8}$ at saturated condition. Growth and yield of rice were attained better at saturated condition than that of the moist soil.
\end{abstract}

Key words: Growth and yield performance of rice, Rice hull, Rice straw, Saw dust, Saline soil

\section{Introduction}

More than $30 \%$ of the cultivable land in Bangladesh is in the coastal area (SRDI 2010) which deserves much attention due to its low productivity especially for rice cultivation. Out of 2.86 million hectares of coastal and off-shore lands about 1.06 million ha of arable lands are affected by varying degrees of salinity. Farmers mostly cultivate low yielding, traditional rice varieties during wet season. Most of the land remains fallow in the dry season (January to May) because of soil salinity, lack of good quality irrigation water and Na-enrichment hampered drainage condition (Khan et al. 2016). Because of salinity, special environmental and hydrological situation exists that restrict the normal crop production throughout the year. Increased level of salinity negatively influences germination, plant growth and reproducibility, physiological processes, including

\footnotetext{
${ }^{1}$ Corresponding author: suma_nur5@yahoo.com
} 
photosynthesis, respiration, transpiration, membrane properties, nutrient balance, enzymatic activity, and metabolic activities, cellular homeostasis and hormone regulation and leads to production of Reactive Oxygen Species (ROS) and in severe stress, it leads to plant death (Hasanuzzaman et al. 2012).

Observations in the recent past indicated that due to increasing degree of salinity of some areas and expansion of salt affected area as a cause of further intrusion of saline water, normal crop production becomes more restricted. In general, soil salinity is believed to be mainly responsible for low land use as well as cropping intensity in the area (Haque 2006). Increased pressure of growing population demand more food. Thus, it has become very important to explore the possibilities of increasing the potential of these saline lands for increased production of crops.Therefore, salt-affected soils must be reclaimed to maintain satisfactory levels of fertility for sustaining food production. The salinity affected coastal areas could be reclaimed by different management strategies, such as improved hydrology, application of agricultural amendments and adaptation/screen out of different salt tolerant crops. Tejada et al. (2006) suggested for the use of organic fertilizers for reclaiming saline and sodic soils, which may increase their fertility but this suggestion need to be assessed. Thus the present study was carried out to evaluate the effects of rice hull, rice straw and saw dust on the growth and yield performance of rice plants in coastal saline soil.

\section{Materials and Methods}

The experiment was conducted with a T. Boro rice cultivar (BRRI 64) at Musulliabad (Lata Chapli), Kalapara, Patuakhali, Bangladesh, during January to June, 2016. Physicochemical characteristics of initial soil (Table 1) were determined following the standard methods.

Rice Hull (RH), Rice Straw (RS) and Saw Dust (SD) were used as indigenous amendments for the studied soil. The experiment was conducted following Completely Randomized block design with 3 factors, such as Rice Hull, Rice Straw and Saw Dust having 3 dosages of each with 3 replications (considered within the plot) under 2 moisture levels (moist and saturated; Fig. 1)). Total number of treatment was $27(3 \mathrm{RH} \times 3 \mathrm{RS} \times 3$ SD: for each moisture level, Table 2). Basal doses of $\mathrm{N}, \mathrm{P}_{2} \mathrm{O}_{5}$ and $\mathrm{K}_{2} \mathrm{O}$ were applied at the rate of 120, 60 and $80 \mathrm{~kg} \mathrm{ha}^{-1}$ as Urea, TSP and MoP, respectively. The whole TSP, MoP and half of the urea were applied during preparation of land. The remaining urea was top dressed in two splits, at active tillering and panicle initiation stage.

Seedlings were collected from the local farmers. Thirty-days-old seedlings of BRRI 64 were transplanted at the rate of 3 seedlings per hill. The hill to hill and row to row distances were 18 and $22 \mathrm{~cm}$, respectively. For proper establishment of the seedlings, the plots in the field were irrigated with pond water for two weeks after transplantation and then the moisture levels were controlled. The field moisture contents of $80 \%$ and $>100 \%$ were considered at the moist and saturated conditions, respectively throughout the growing period. Intercultural operations were performed as required. 
Table 1. Physico-chemical properties of initial soil on oven dry basis.

\begin{tabular}{|c|c|}
\hline Properties & Values \\
\hline Particle density $\left(\mathrm{g} \mathrm{cm}^{-3}\right)$ & 2.53 \\
\hline Bulk density $\left(\mathrm{g} \mathrm{cm}^{-3}\right)$ & 1.37 \\
\hline Porosity $(\%)$ & 45.81 \\
\hline Moisture content (\%; Black 1965) & 3.31 \\
\hline Textural class (Hydrometer method; Piper 1966) & Clay loam \\
\hline pH (1:2.5; Jackson 1973) & 6.90 \\
\hline EC (dS m${ }^{-1} ;$ Saturation extract, $1: 5 ;$ Richards 1954$)$ & 3.96 \\
\hline Organic carbon $\left(\mathrm{g} \mathrm{kg}^{-1}\right.$; Nelson and Sommers 1982) & 7.80 \\
\hline Total Nitrogen $\left(\mathrm{g} \mathrm{kg}^{-1}\right.$; Jackson 1973) & 0.60 \\
\hline Available Nitrogen ( $\mathrm{mg} \mathrm{kg}^{-1} ; 1 \mathrm{~N} \mathrm{KCl}$; Jackson 1973) & 54.55 \\
\hline Available Phosphorus (mg kg-1; Olsen et al. 1954) & 12.58 \\
\hline Available Potassium (mg kg ; Pratt 1965) & 25.00 \\
\hline \multicolumn{2}{|l|}{ Exchangeable Cations (c mol kg-1; $\left.1 \mathrm{~N} \mathrm{CH}_{3} \mathrm{COONH}_{4}\right)$} \\
\hline Sodium (flame photometer) & 3.91 \\
\hline Potassium (flame photometer) & 0.64 \\
\hline Calcium $\left(\mathrm{AAS}^{*}\right)$ & 1.87 \\
\hline Magnesium (AAS*) & 3.26 \\
\hline \multicolumn{2}{|l|}{ Water Soluble Anions (c mol kg ${ }^{-1}$ ) } \\
\hline Chloride (0.005 N AgNO 3 ; Richards 1954) & 2.87 \\
\hline Sulphate $\left(\mathrm{BaCl}_{2} ;\right.$ Richards 1954$)$ & 1.45 \\
\hline Bicarbonate $\left(0.05 \mathrm{~N} \mathrm{H}_{2} \mathrm{SO}_{4}\right.$; Richards 1954) & 0.47 \\
\hline Carbonate $\left(0.05 \mathrm{~N} \mathrm{H}_{2} \mathrm{SO}_{4}\right.$; Richards 1954$)$ & $\mathrm{ND}^{\#}$ \\
\hline Cation Exchange Capacity (c mol kg-1; Black 1965) & 18.67 \\
\hline Sodium Adsorption Ratio (Richards 1954) & 7.72 \\
\hline Exchangeable Sodium Percentage (Richards 1954) & 20.92 \\
\hline
\end{tabular}

*AAS = Atomic Absorption Spectrophotometer, ${ }^{\#} \mathrm{ND}=$ Not in detectable range.

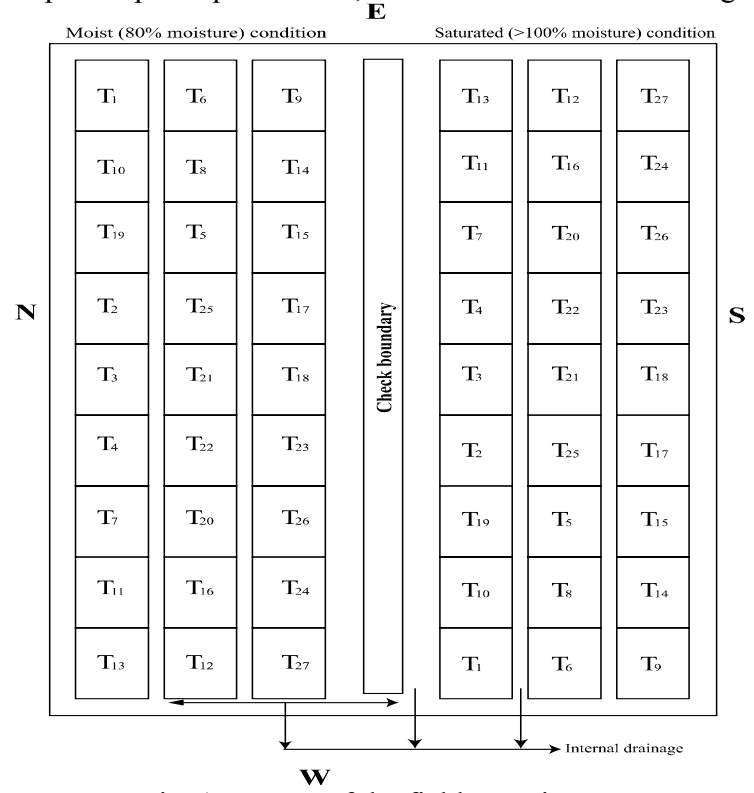

Fig. 1. Layout of the field experiment. 
Table 2. Treatment combinations of the experiment.

\begin{tabular}{|c|c|c|c|c|}
\hline \multicolumn{2}{|r|}{ Treatment } & \multicolumn{3}{|c|}{ Rate $\left(\mathrm{t} \mathrm{ha}^{-1}\right)$} \\
\hline No. & Denotation & Rice Hull (RH) & Rice Straw (RS) & Saw Dust (SD) \\
\hline $\mathrm{T}_{1}$ & $\mathrm{RH}_{0} \mathrm{RS}_{0} \mathrm{SD}_{0}$ & 0 & 0 & 0 \\
\hline $\mathrm{T}_{2}$ & $\mathrm{RH}_{0} \mathrm{RS}_{0} \mathrm{SD}_{4}$ & 0 & 0 & 4 \\
\hline $\mathrm{T}_{3}$ & $\mathrm{RH}_{0} \mathrm{RS}_{0} \mathrm{SD}_{8}$ & 0 & 0 & 8 \\
\hline $\mathrm{T}_{4}$ & $\mathrm{RH}_{0} \mathrm{RS}_{4} \mathrm{SD}_{0}$ & 0 & 4 & 0 \\
\hline $\mathrm{T}_{5}$ & $\mathrm{RH}_{0} \mathrm{RS}_{4} \mathrm{SD}_{4}$ & 0 & 4 & 4 \\
\hline $\mathrm{T}_{6}$ & $\mathrm{RH}_{0} \mathrm{RS}_{4} \mathrm{SD}_{8}$ & 0 & 4 & 8 \\
\hline $\mathrm{T}_{7}$ & $\mathrm{RH}_{0} \mathrm{RS}_{8} \mathrm{SD}_{0}$ & 0 & 8 & 0 \\
\hline $\mathrm{T}_{8}$ & $\mathrm{RH}_{0} \mathrm{RS}_{8} \mathrm{SD}_{4}$ & 0 & 8 & 4 \\
\hline $\mathrm{T}_{9}$ & $\mathrm{RH}_{0} \mathrm{RS}_{8} \mathrm{SD}_{8}$ & 0 & 8 & 8 \\
\hline $\mathrm{T}_{10}$ & $\mathrm{RH}_{4} \mathrm{RS}_{0} \mathrm{SD}_{0}$ & 4 & 0 & 0 \\
\hline $\mathrm{T}_{11}$ & $\mathrm{RH}_{4} \mathrm{RS}_{0} \mathrm{SD}_{4}$ & 4 & 0 & 8 \\
\hline $\mathrm{T}_{12}$ & $\mathrm{RH}_{4} \mathrm{RS}_{0} \mathrm{SD}_{8}$ & 4 & 0 & 8 \\
\hline $\mathrm{T}_{13}$ & $\mathrm{RH}_{4} \mathrm{RS}_{4} \mathrm{SD}_{0}$ & 4 & 4 & 0 \\
\hline $\mathrm{T}_{14}$ & $\mathrm{RH}_{4} \mathrm{RS}_{4} \mathrm{SD}_{4}$ & 4 & 4 & 4 \\
\hline $\mathrm{T}_{15}$ & $\mathrm{RH}_{4} \mathrm{RS}_{4} \mathrm{SD}_{8}$ & 4 & 4 & 8 \\
\hline $\mathrm{T}_{16}$ & $\mathrm{RH}_{4} \mathrm{RS}_{8} \mathrm{SD}_{0}$ & 4 & 8 & 0 \\
\hline $\mathrm{T}_{17}$ & $\mathrm{RH}_{4} \mathrm{RS}_{8} \mathrm{SD}_{4}$ & 4 & 8 & 4 \\
\hline $\mathrm{T}_{18}$ & $\mathrm{RH}_{4} \mathrm{RS}_{8} \mathrm{SD}_{8}$ & 4 & 8 & 8 \\
\hline $\mathrm{T}_{19}$ & $\mathrm{RH}_{8} \mathrm{RS}_{0} \mathrm{SD}_{0}$ & 8 & 0 & 0 \\
\hline $\mathrm{T}_{20}$ & $\mathrm{RH}_{8} \mathrm{RS}_{0} \mathrm{SD}_{4}$ & 8 & 0 & 4 \\
\hline $\mathrm{T}_{21}$ & $\mathrm{RH}_{8} \mathrm{RS}_{0} \mathrm{SD}_{8}$ & 8 & 0 & 8 \\
\hline $\mathrm{T}_{22}$ & $\mathrm{RH}_{8} \mathrm{RS}_{4} \mathrm{SD}_{0}$ & 8 & 4 & 0 \\
\hline $\mathrm{T}_{23}$ & $\mathrm{RH}_{8} \mathrm{RS}_{4} \mathrm{SD}_{4}$ & 8 & 4 & 4 \\
\hline $\mathrm{T}_{24}$ & $\mathrm{RH}_{8} \mathrm{RS}_{4} \mathrm{SD}_{8}$ & 8 & 4 & 8 \\
\hline $\mathrm{T}_{25}$ & $\mathrm{RH}_{8} \mathrm{RS}_{8} \mathrm{SD}_{0}$ & 8 & 8 & 0 \\
\hline $\mathrm{T}_{26}$ & $\mathrm{RH}_{8} \mathrm{RS}_{8} \mathrm{SD}_{4}$ & 8 & 8 & 4 \\
\hline $\mathrm{T}_{27}$ & $\mathrm{RH}_{8} \mathrm{RS}_{8} \mathrm{SD}_{8}$ & 8 & 8 & 8 \\
\hline
\end{tabular}

Plant height, tiller number, straw and grain yields were recorded after harvesting the crop at maturity. The significance of different treatments was assessed by Duncan's New Multiple Range Test (DMRT) and Tukey comparisons.

\section{Results and Discussion}

\section{Plant Height and Tiller Production}

Growth period and environment under which plant is grown are the important factors in the life history of rice plant. It is convenient to regard the life history of rice in terms of three growth stages: vegetative, reproductive and ripening (Yoshida 1981). The vegetative stage is characterized by tillering and gradual increase in plant height. Plant height and tiller production at different growth stages are important such as for the selection of plants for low, medium and high lands, fertilizing and other cultural practices. Moreover, the present study was made on problematic soils, where plant life cycle is sometimes irregular. Accordingly, plant height and tiller production of rice were considered for this present study. 


\section{Plant Height}

Plant height increased significantly $(\mathrm{p} \leq 0.05)$ with the advent of time and with the rates of application of the indigenous organic amendments viz. rice hull, rice straw and saw dust which might be due to maintenance of favorable conditions for plant growth resulting an improvement in plant heights (Fig. 2). The individual variables such as rice hull, rice straw, saw dust and their combination produced statistically significant increase in plant height both at moist and saturated conditions. The highest heights of rice plant ( $89 \mathrm{~cm}$ in moist and $101 \mathrm{~cm}$ in saturated condition) were recorded in the $\mathrm{RH}_{8} \mathrm{RS}_{8} \mathrm{SD}_{8}$ treatment, which received the highest rates of combination of these 3 amendments. The lowest plant heights $(73 \mathrm{~cm}$ in moist and $77 \mathrm{~cm}$ in saturated condition) were recorded in the control condition $\left(\mathrm{RH}_{0} \mathrm{RS}_{0} \mathrm{SD}_{0}\right)$.

Kamara et al. (2015) reported that rice plants grown on soils treated with rice straw were significantly $(\mathrm{p}<0.05)$ taller than those grown on soils without treatment. Incorporation of rice straw into the soil combined with cattle manure gave the maximum plant height (Parham et al. 2002).

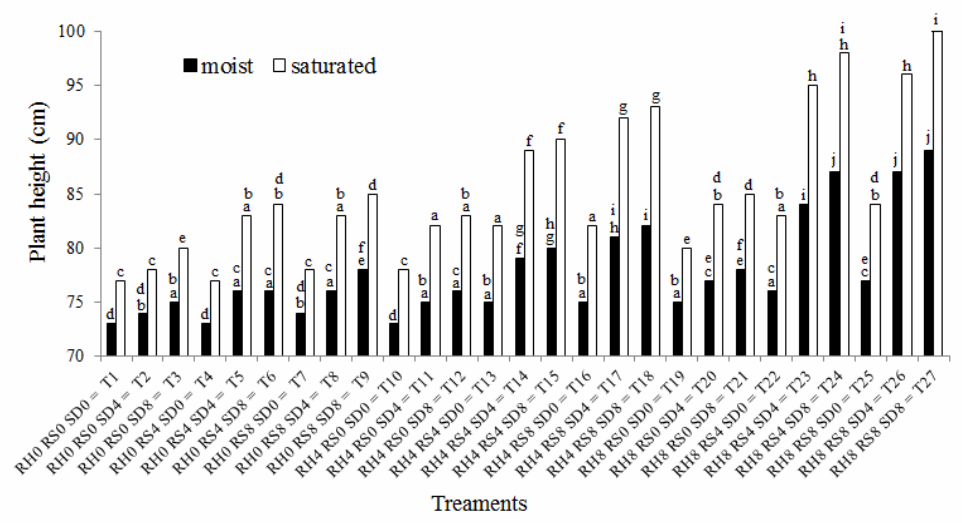

Fig. 2. Height of rice plant (BRRI 64) as influenced by the application of rice hull, rice straw, saw dust and moisture conditions.

Tiller Production: The numbers of productive tillers counted at moist and saturated conditions were found to be influenced by applied treatments (Fig. 3). The tiller production of rice was significantly $(p \leq 0.05)$ higher over control in most of the treatments irrespective of the rates of rice hull, rice straw and saw dust in both moist and saturated conditions (Fig. 3). The maximum numbers of tillers were observed in $\mathrm{RH}_{8} \mathrm{RS}_{8} \mathrm{SD}_{8}$ and $\mathrm{RH}_{8} \mathrm{RS}_{4} \mathrm{SD}_{8}$, followed by $\mathrm{RH}_{8} \mathrm{RS}_{8} \mathrm{SD}_{4}, \mathrm{RH}_{8} \mathrm{RS}_{4} \mathrm{SD}_{4}$ and $\mathrm{RH}_{4} \mathrm{RS}_{8} \mathrm{SD}_{8}$ treatments at saturated condition. The actual numbers of tillers were observed (24 - 33\%) more than those shown at the maturity stage of rice growth (Fig. 3) and the decrement of the numbers of tillers were almost a usual phenomena of rice production under this 
problematic saline soil. However, the increments of number $(17-183 \%)$ of tillers by the application of organic amendments in the present study might be the resultant effect of addition of organic matter in turn release of nutrients to the soil.

Straw Yield: The straw dry matter yields were found to be higher at saturated condition as compared to moist condition in all treatments (Tables 3 and 4). The maximum straw yield was attained by the $\mathrm{RH}_{8} \mathrm{RS}_{8} \mathrm{SD}_{8}$ treatment while the treatments $\mathrm{RH}_{8} \mathrm{RS}_{8} \mathrm{SD}_{4}, \mathrm{RH}_{8} \mathrm{RS}_{4} \mathrm{SD}_{8}$ and $\mathrm{RH}_{8} \mathrm{RS}_{4} \mathrm{SD}_{4}$ were ranked second at the saturated condition of the soil. The trends of influence of the other treatments were almost similar with their higher rates and combinations. Straw yields were observed significant $(p \leq 0.05)$ for different levels of rice hull, rice straw and saw dust alone and their combinations in both the soil moisture conditions. The straw yields in treatments having the lower ECe values were found to be superior to that of the higher ECe values. Rice hull, rice straw and saw dust applied together at the rate of $8 \mathrm{tha}^{-1}$ under saturated condition were found to be effective in increasing straw yield of rice. The results demonstrated that the application of rice hull, rice straw and saw dust alone and in combination were found to improve the dry matter production of straw at saturated condition through imparting favorable conditions for the growth and uptake of nutrients by rice.

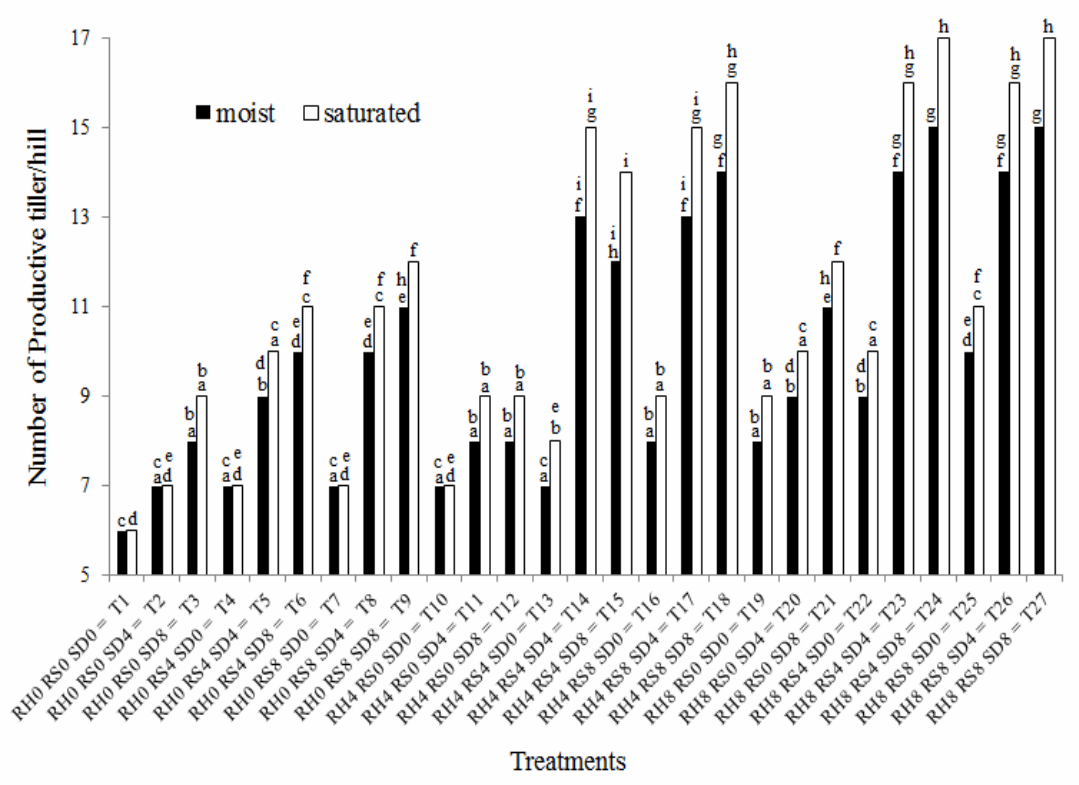

Fig. 3. Tiller production of rice (BRRI 64) as influenced by the application of rice hull, rice straw, saw dust and moisture conditions. 
Table 3. Straw yield $\left(\mathrm{t} \mathrm{ha}^{-1}\right)$ of rice under moist condition as influenced by the application of rice hull, rice straw and saw dust in saline soil.

\begin{tabular}{|c|c|c|c|c|c|c|}
\hline \multirow[t]{2}{*}{$\mathrm{RH} \times \mathrm{RS} \times \mathrm{SD}$} & \multirow{2}{*}{$\begin{array}{l}\text { Rice Straw } \\
\left(\text { RS: } t_{\text {ha }}^{-1}\right)\end{array}$} & \multicolumn{3}{|c|}{ Saw Dust (SD: $\mathrm{t} \mathrm{ha}^{-1}$ ) } & \multirow[t]{2}{*}{ RH- mean } & \multirow[t]{2}{*}{ RS- mean } \\
\hline & & $\mathbf{0}$ & 4 & 8 & & \\
\hline \multirow{9}{*}{ 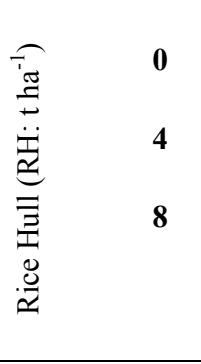 } & $\mathbf{0}$ & 3.61 & $3.9 \mathrm{kl}$ & $4.0 \mathrm{k}$ & \multirow{3}{*}{4.19} & \multirow{3}{*}{$4.22\left(0 \mathrm{tha}^{-1}\right)$} \\
\hline & 4 & $3.9 \mathrm{kl}$ & $4.4 \mathrm{ij}$ & $4.6 \mathrm{ghi}$ & & \\
\hline & 8 & $4.1 \mathrm{jk}$ & $4.5 \mathrm{hi}$ & 4.7 fghi & & \\
\hline & $\mathbf{0}$ & $3.9 \mathrm{kl}$ & $4.5 \mathrm{hi}$ & $4.4 \mathrm{ij}$ & \multirow[t]{2}{*}{4.64} & \multirow{3}{*}{$4.74\left(4 \mathrm{tha}^{-1}\right)$} \\
\hline & 4 & $4.4 \mathrm{ij}$ & $4.9 \mathrm{efg}$ & $5.0 \mathrm{def}$ & & \\
\hline & 8 & 4.6 ghi & $5.0 \mathrm{def}$ & $5.1 \mathrm{cde}$ & \multirow[t]{4}{*}{5.01} & \\
\hline & $\mathbf{0}$ & $4.1 \mathrm{jk}$ & 4.7 fghi & $4.9 \mathrm{efg}$ & & \\
\hline & 4 & 4.7 fghi & $5.3 \mathrm{bcd}$ & $5.5 \mathrm{ab}$ & & $4.88\left(8 \mathrm{tha}^{-1}\right)$ \\
\hline & 8 & $4.8 \mathrm{efgh}$ & $5.4 \mathrm{abc}$ & $5.7 \mathrm{a}$ & & \\
\hline \multicolumn{2}{|c|}{ Saw Dust (SD)-mean } & 4.23 & 4.73 & 4.87 & & \\
\hline
\end{tabular}

In a column and row, means followed by a common letter are not significantly different at $5 \%$ level (Tukey comparisons).

Table 4. Straw yield $\left(\mathrm{t} \mathrm{ha}^{-1}\right)$ of rice under saturated condition as influenced by the application of rice hull, rice straw and saw dust in saline soil.

\begin{tabular}{|c|c|c|c|c|c|c|c|}
\hline \multicolumn{2}{|c|}{$\mathrm{RH} \times \mathrm{RS} \times \mathrm{SD}$} & \multirow{2}{*}{$\begin{array}{l}\text { Rice Straw } \\
\left(\text { RS: } t_{\text {ha }}^{-1}\right)\end{array}$} & \multicolumn{3}{|c|}{ Saw Dust (SD: $\mathrm{t} \mathrm{ha}^{-1}$ ) } & \multirow[t]{2}{*}{ RH- mean } & \multirow[t]{2}{*}{ RS- mean } \\
\hline & & & $\mathbf{0}$ & 4 & 8 & & \\
\hline \multirow{9}{*}{ 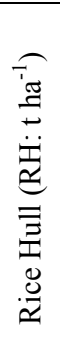 } & & 0 & 3.91 & $4.2 \mathrm{kl}$ & $4.3 \mathrm{k}$ & & \multirow{3}{*}{$4.60\left(0 \mathrm{t} \mathrm{ha}^{-1}\right)$} \\
\hline & \multirow[t]{2}{*}{$\mathbf{0}$} & 4 & $4.2 \mathrm{kl}$ & $4.8 \mathrm{j}$ & $5.1 \mathrm{hij}$ & 4.57 & \\
\hline & & 8 & $4.4 \mathrm{k}$ & $5.0 \mathrm{ij}$ & $5.2 \mathrm{ghi}$ & & \\
\hline & \multirow[t]{2}{*}{4} & 0 & $4.2 \mathrm{kl}$ & $5.0 \mathrm{ij}$ & $4.8 \mathrm{j}$ & 5.18 & \multirow{3}{*}{$5.28\left(4 \mathrm{tha}^{-1}\right)$} \\
\hline & & 4 & $4.8 \mathrm{j}$ & $5.5 \mathrm{efg}$ & $5.7 \mathrm{def}$ & & \\
\hline & \multirow[t]{4}{*}{8} & 8 & $5.1 \mathrm{hij}$ & $5.7 \mathrm{def}$ & $5.8 \mathrm{cde}$ & 5.58 & \\
\hline & & 0 & $4.4 \mathrm{k}$ & $5.2 \mathrm{ghi}$ & $5.4 \mathrm{fgh}$ & & \multirow{3}{*}{$5.44\left(8 \mathrm{tha}^{-1}\right)$} \\
\hline & & 4 & $5.2 \mathrm{ghi}$ & $6.0 \mathrm{bcd}$ & $6.2 \mathrm{ab}$ & & \\
\hline & & 8 & $5.3 \mathrm{ghi}$ & $6.1 \mathrm{abc}$ & $6.4 \mathrm{a}$ & & \\
\hline \multicolumn{3}{|c|}{ Saw Dust (SD)-mean } & 4.61 & 5.28 & 5.43 & & \\
\hline
\end{tabular}

In a column and row, means followed by a common letter are not significantly different at $5 \%$ level (Tukey comparisons).

Grain Yield: The analysis of variance of the data evince that the grain yields of rice significantly $(\mathrm{p} \leq 0.05)$ varied by the individual application of rice hull, rice straw, saw dust $\left(0,4,8 \mathrm{tha}^{-1}\right)$ and moisture conditions and their combined effects were found to be more effective and significant at the higher levels of these treatments (Tables 5 and 6). The treatment means also demonstrated that the grain yield increased significantly ( $\mathrm{p}$ $\leq 0.05$ ) over the control with rate of the treatments. The single effect of rice hull, rice straw and saw dust were found to be effective in increasing the grain yield over control 
but their combinations were more effective under both moisture levels. Generally, the grain yield was better in saturated condition than that obtained from moist condition in all the treatments (Tables 5 and 6). The highest yield $\left(6.6 \mathrm{t} \mathrm{ha}^{-1}\right)$ was recorded in $\mathrm{RH}_{8} \mathrm{RS}_{8} \mathrm{SD}_{8}$ treatment followed by $\mathrm{RH}_{8} \mathrm{RS}_{8} \mathrm{SD}_{4}, \mathrm{RH}_{8} \mathrm{RS}_{4} \mathrm{SD}_{8}, \mathrm{RH}_{8} \mathrm{RS}_{4} \mathrm{SD}_{4}$ and $\mathrm{RH}_{4} \mathrm{RS}_{8} \mathrm{SD}_{8}$ at saturated condition. The results are partially agreed with earlier findings of Kaniz and Khan (2013) and Iqbal (2016). They reported that the growth and yield of rice grown on saline soils increased significantly with the application of rice hull, gypsum and saw dust. Kaniz and Khan also suggested that the lower dosage $\left(5 \mathrm{t} \mathrm{ha}^{-1}\right)$ was effective but the higher dosage $\left(10 \mathrm{t} \mathrm{ha}^{-1}\right)$ behaved negatively in improving the adverse effect of salinity and yield performance of saline sensitive rice variety.

Results suggest that the rice yields obtained from the studied saline soil increased from 3.4 to $6.6 \mathrm{t} \mathrm{ha}^{-1}$ due to the application of rice hull, rice straw and saw dust each at the rates of 4 and $8 \mathrm{tha}^{-1}$ under variable moisture conditions, which is encouraging and environmentally sound if these amendments are available locally.

Table 5. Grain yield $\left(\mathrm{t} \mathrm{ha}^{-1}\right)$ of rice under moist condition as influenced by the application of rice hull, rice straw and saw dust in saline soil.

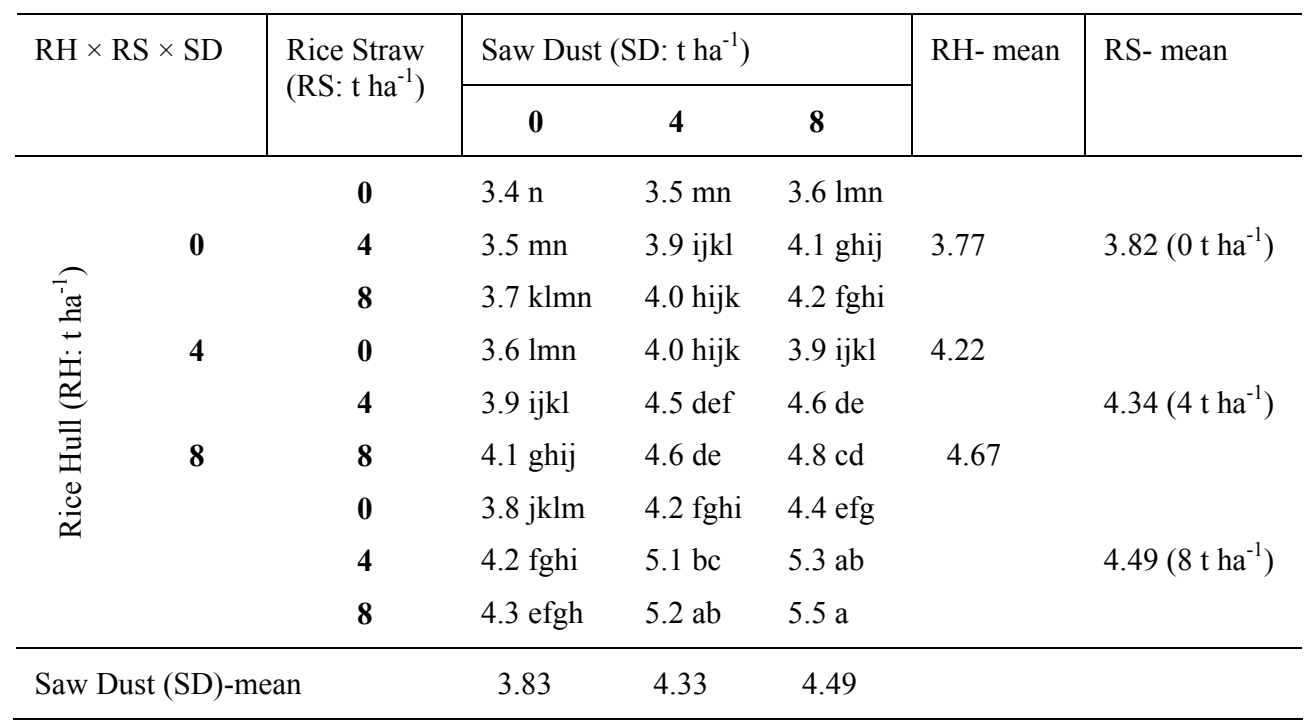

In a column and row, means followed by a common letter are not significantly different at $5 \%$ level (Tukey comparisons). 
Table 6. Grain yield $\left(\mathrm{t} \mathrm{ha}^{-1}\right)$ of rice under saturated condition as influenced by the application of rice hull, rice straw and saw dust in saline soil.

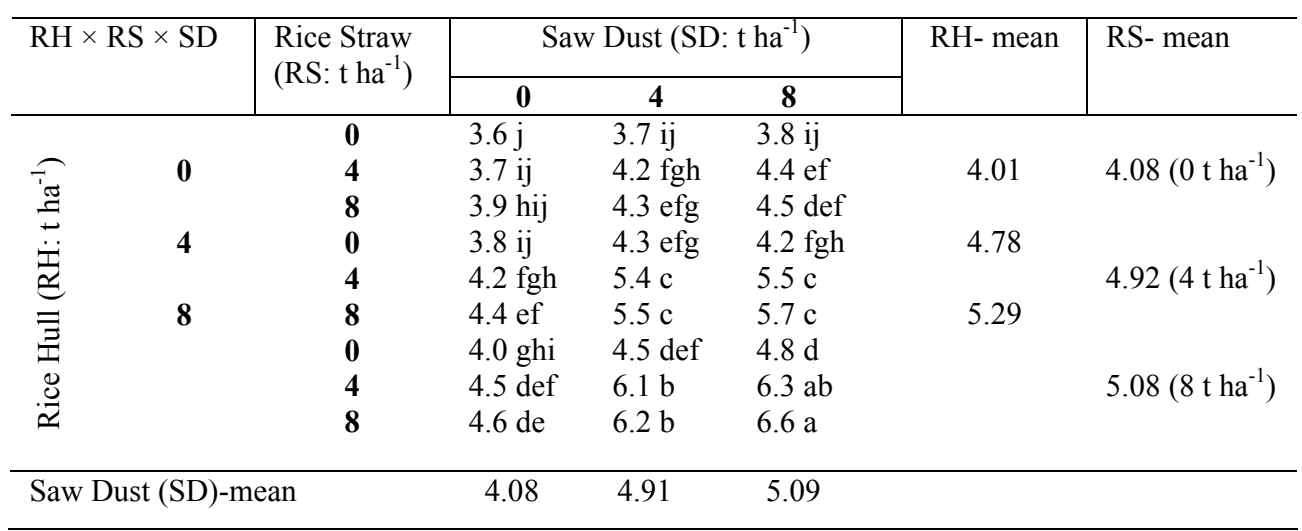

In a column and row, means followed by a common letter are not significantly different at $5 \%$ level (Tukey comparisons).

Regardless of rates of these organic amendments, rice hull, rice straw and saw dust exerted almost similar and better growth-yield performances of rice under saturated soil condition than those of the moist condition of the saline soil, which suggests that soil water is an important factor to manage these organic amendments more effectively in saline soil. However, further research is still needed to work out the dosages of these organic amendments for the production of rice under saline environments. The potential of the amending materials for salt tolerance and their adaption by farmers under variable climates, crop response and socio-economic considerations should also be kept in mind for further practices and recommendation.

\section{Acknowledgements}

The study was carried out under the project entitled 'Multidisciplinary Approaches for Green Transformation and Development of Agriculture in Salt-affected Coastal Soils Under Changing Climatic Conditions' funded by the Ministry of Science and Technology, Government of the People's Republic of Bangladesh. We are also grateful to the Ministry of Science and Technology for providing NST fellowships to Suma Akter and Mohammed Sadid Hossain.

\section{References}

Black, C.A. (ed.) 1965. Methods of soil analysis, Part 2, Series 9, pp. 894-1372, Am Soc. Agron. Inst. Publ., Madison, WI.

Haque, S.A. 2006. Salinity problems and crop production in coastal regions of Bangladesh. Pak. J. Bot. 38 (5): 1359-1365. 
Hasanuzzaman, M., M.A. Hossain, J.A. Teixeira da Silva and M. Fujita. 2012. Plant responses and tolerance to abiotic oxidative stress: antioxidant defense is a key factor in crop stress and its management: perspectives and strategies, V. Bandi, A.K. Shanker, C. Shanker and M. Mandapaka, Springer, Berlin, Germany, Eds. 261-316.

Iqbal, T. 2016. Rice straw amendment ameliorates harmful effect of salinity and increases nitrogen availability in a saline paddy soil. Journal of the Saudi Society of Agricultural Sciences (In Press). http://dx.doi.org/10.1016/j.jssas. 2016.11.002

Jackson, M.L. 1973. Soil Chemical Analysis, Prentice Hall of India Pvt. Ltd., New Delhi. 36-196.

Kamara, A., H.S. Kamara and M.S. Kamara. 2015. Effects of Rice Straw Biochar on Soil Quality and the Early Growth and Biomass Yield of Two Rice Varieties. Agricultural Sciences. 6: $798-806$

Kaniz, F. and H.R. Khan. 2013. Reclamation of saline soil using gypsum, rice hull and sawdust in relation to rice production. $J$ Adv Sci Res, 4(3): 1-5.

Khan, H.R., S.M. Kabir and M.M.A. Bhuiyan. 2016. Effects of selected treatments and techniques for the reclamation and improvement of Cheringa acid sulfate soil under rice production in the coastal plain of Cox's Bazar. J. Asiat. Soc. Bangladesh, Sci. 42 (1): 29-40.

Nelson, D.W. and L.E. Sommers. 1982. Total carbon, organic carbon and organic matter. In Methods of Soil Analysis, part 2. Agron. Series 9. Page A.L. (ed.). pp. 539-579, Am. Soc. Agron., Publ. Madison, WI, USA.

Olsen, S.R., C.V. Cale, F.S. Watanabe and L.A. Dean. 1954. Estimation of available phosphorus in soils by extraction with sodium bicarbonate. USDA Circ., 939.

Parham, J.A., S.P. Deng, W.R. Roun and G.V. Johnson. 2002. Long-term cattle manure application in soil. Bio Fertile Soils. 35: 328-337.

Piper, C.S. 1966. Soil and Plant Analysis, pp. 77. Hano Publ. Bombay, India.

Pratt P.F. 1965. Methods of Soil Analysis (Black C.A. Ed.) pp.1022. Am. Soc. Agron. Madison, Wisconsin, USA.

Richards, L.A. (ed.). 1954. Diagnosis and improvement of saline and alkali soils. In USDA Handbook No. 60. pp. 84-156. US Govt. Print. Office, Washington, USA.

SRDI. 2010. Saline soils of Bangladesh. SRMAF project. Ministry of Agriculture, Govt. of the people's republic of Bangladesh, Farmgate, Dhaka.

Tejada, M., C. Garcia, J.L. Gonzalez and M.T. Hernandez. 2006. Use of organic amendment as a strategy for saline soil remediation: Influence on the physical, chemical and biological properties of soil. Soil Biol. Biochem. 38: 1413-1421. 